\title{
Unilateral transient mydriasis and ptosis after botulinum toxin injection for a cosmetic procedure
}

This article was published in the following Dove Press journal:

Clinical Ophthalmology

12 February 2015

Number of times this article has been viewed

\author{
Sezen Akkaya' \\ Hatice Kübra Kökcen' \\ Tuğba Atakan² \\ 'Fatih Sultan Mehmet Education \\ and Training Hospital, Ophthalmology \\ Clinics, Bostancı, Istanbul, ${ }^{2}$ Aksaray \\ Hospital, Ophthalmology Clinics, \\ Konya, Turkey
}

\begin{abstract}
We report a case of unilateral transient mydriasis and ptosis after botulinum toxin injection applied by a medical doctor for a cosmetic procedure. A 36-year-old nurse was referred to our eye clinic with unilateral mydriasis and ptosis in the right eye 3 days after botulinum toxin injection for a cosmetic procedure. Botulinum toxin was applied to her eye by a doctor at her hospital who was not an ophthalmologist. She was treated with topical apraclonidine $0.5 \%$ ophthalmic solution. Her ptosis decreased to $2 \mathrm{~mm}$ with apraclonidine and her visual axis improved. Mydriasis was present for 3 weeks and then disappeared. Mild ptosis continued for 3 months, then resolved completely. Patients seeking treatment with botulinum toxin A for cosmetic purposes should be warned about the possibility of ptosis and mydriasis after injection. If these side effects are seen, the patient must be referred to an ophthalmologist for appropriate management.
\end{abstract}

Keywords: botulinum toxin, mydriasis, ptosis

\section{Introduction}

Botulinum toxin A (BTX-A) was first used for esthetic purposes in 1990 to reduce wrinkles caused by facial muscle. Its effect starts 3-4 days after application and lasts for 4-6 months. ${ }^{1}$

All medical doctors, from plastic surgeons to dermatologists, can administer BTX-A injections effectively and safely. Ophthalmologists are also performing this procedure for blepharospasm. ${ }^{2}$ Patients may also present to an ophthalmologist because of the ophthalmological side effects of BTX-A. For this reason, the ophthalmologist must take a detailed history from the patient if there is ptosis.

\section{Case report}

A 36-year-old woman was referred to the eye clinic at Fatih Sultan Mehmet Training and Research Hospital with unilateral mydriasis and ptosis in the right eye (Figures 1 and 2). Right upper eyelid margin was at the level of the pupil, 3 days after botulinum toxin injection for a cosmetic procedure. The patient was a nurse and the BTX-A was administered by a doctor at her hospital who was not an ophthalmologist. The total cumulative dose of BTX-A injected was 35 IU to the right side and 25 IU to the left side. BTX-A was injected bilaterally to the orbicularis oculi, corrugator supercili, and procerus muscles to reduce the wrinkles.

On presentation, her right pupil measured $6 \mathrm{~mm}$ and was fixed, with no direct or consensual response to light, and her left pupil was $3 \mathrm{~mm}$ and had a normal light response. There was a $3 \mathrm{~mm}$ difference in diameter between the pupils.
Correspondence: Sezen Akkaya Güzeltepe Mah Prof Dr Beynun Akyavaș Cad Pembe Evler Sitesi, No I4, Çengelköy, Üsküdar-İstanbul, Turkey Tel +53 24024898

Email drsezenakkaya@gmail.com 
The patient had no previous history of lid surgery or botulinum toxin injection. Best corrected visual acuity was 20/20 in both eyes. Biomicroscopic examination of the anterior segment was normal. Intraocular pressure was $12 \mathrm{mmHg}$ in both eyes. Thorough dilated fundus examination was normal. Margin reflex distance was $2 \mathrm{~mm}$ in the right eye and $6 \mathrm{~mm}$ in the left eye. Levator function was $10 \mathrm{~mm}$ in the right eye and $16 \mathrm{~mm}$ in the left eye. Bell's phenomenon was normal. There was no abnormality of extraocular movements and no jaw winking was observed (Figure 1). Cranial magnetic resonance imaging revealed no optic nerve or cerebral dysfunction. There was no apparent afferent pupillary defect, as judged by the reaction of the left pupil.

The patient was counseled that the ptosis and mydriasis would not be permanent. She was treated with topical apraclonidine $0.5 \%$ ophthalmic solution, which decreased her ptosis to $2 \mathrm{~mm}$. Her visual axis improved, and her eye opening improved after 3 days of treatment with apraclonidine. On examination, there was only a $2 \mathrm{~mm}$ ptosis in the right eye (margin reflex distance $4 \mathrm{~mm}$ ) but the mydriasis was unchanged. Her mydriasis was present for 3 weeks and then disappeared. Mild ptosis continued for 3 months, then resolved completely (Figure 3).

\section{Discussion}

Botulinum neurotoxins inhibit the release of acetylcholine and act primarily at the peripheral cholinergic synapses. These agents act at the neuromuscular junction in skeletal muscle, causing transient muscle paresis. ${ }^{3}$ However, botulinum toxins also inhibit the release of acetylcholine at the sympathetic ganglia and at the preganglionic and postganglionic nerve terminals in the parasympathetic nervous system. ${ }^{4}$ People who are systemically poisoned with botulinum toxins characteristically have fixed mid-dilated pupils due to paralysis of the sympathetic and parasympathetic innervation to the

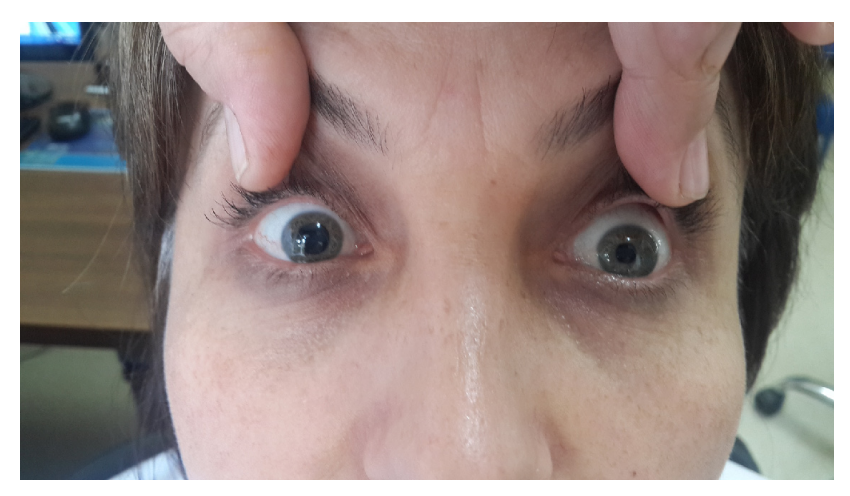

Figure I Mydriasis after botulinum toxin injection in the right eye. iris. Botulinum toxins could therefore cause pupil dilatation by uptake into the parasympathetic neurons at the level of the ciliary ganglion or the parasympathetic neuromuscular junctions in the sphincter pupillae of the iris. ${ }^{5}$ It has been shown in animal studies that botulinum toxin injected intracamerally or near the ciliary ganglion causes mydriasis. ${ }^{3}$ Persistent mydriasis has been reported after medial rectus muscle injection of botulinum toxin for esotropia in a child. ${ }^{6}$

There are no reports in the literature on reversible mydriasis secondary to cosmetic procedures. We believe that botulinum toxin had been administered at a high dose in our patient, and that the cumulative BTX-A dose to the right eye was more than that to the left eye.

Transient mydriasis has been observed with experimental retrobulbar botulinum toxin injection at doses of 1.5 and $2.5 \mathrm{ng}$ in rats, with the mydriasis resolving within 12 weeks. ${ }^{7}$ In a rabbit model, intravitreal injection of 1.25 to 25 units caused mydriasis lasting for 3 weeks. Five cases of transient mydriasis have been reported in humans. In these five cases, after botulinum toxin injection to extraocular muscles, mostly the lateral rectus muscles, transient mydriasis was shown with Adie's pupils. The most likely suggested cause was injury to the ciliary ganglion, resulting in weakened accommodation. None of the cases, however, showed mydriasis persisting for more than a few weeks. ${ }^{7,8}$

Botulinum toxin can also cause ptosis. Prevention of ptosis requires care during injection and in the post-procedure period. When injecting botulinum toxin, care should be taken not to inject the lower frontalis or orbicularis oculi muscles at sites that are lateral to the mid-pupillary line, and the needle should be pointing superiorly away from the orbit to prevent the toxin from denervating the levator muscles that raise the eyelid, resulting in ptosis. ${ }^{9,10}$

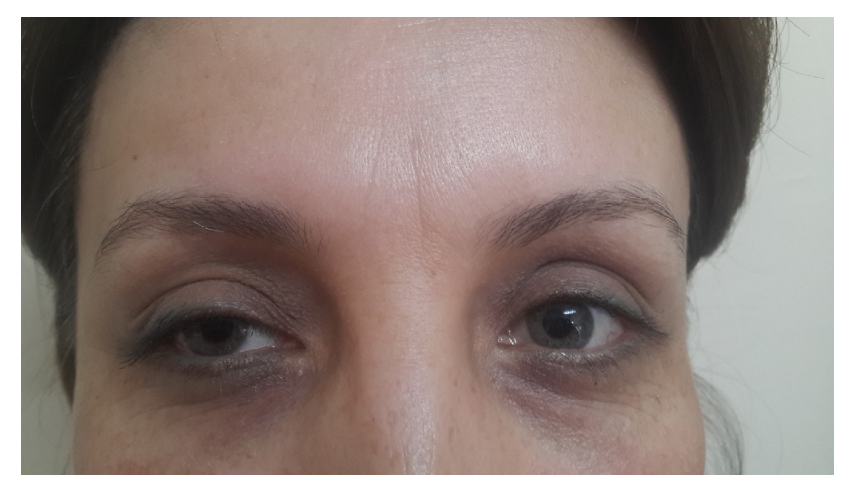

Figure 2 Ptosis after botulinum toxin injection in the right eye. 


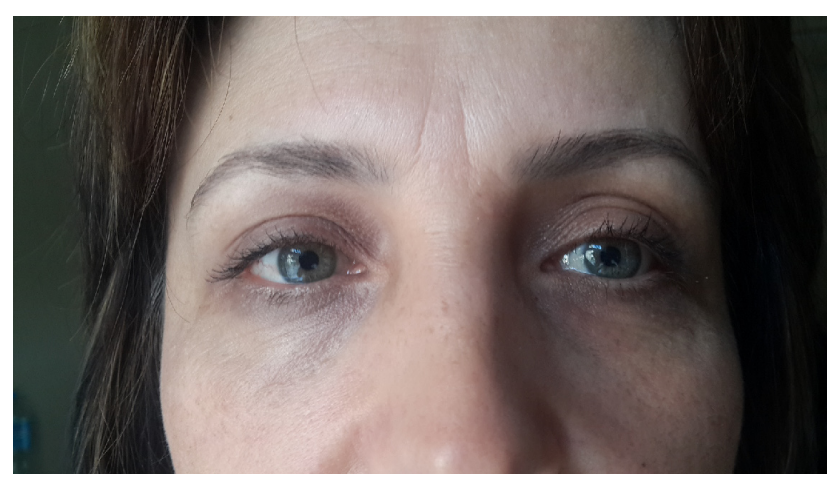

Figure 3 Ptosis and mydriasis resolved.

Apraclonidine successfully reversed ptosis due to botulinum toxin injection in our patient. Apraclonidine is an alpha-adrenergic receptor agonist ${ }^{9}$ that directly stimulates sympathetic innervation of the superior tarsal muscle and decreases ptosis. There is currently no treatment for botulinum toxin-induced ptosis. Patients who suffer such a complication have to wait for several weeks until the effects of the toxin wear off. This case report suggests that apraclonidine can provide a reversal option for physicians and their patients.

Before botulinum injection for cosmetic purposes or to treat blepharospasm, patients should be warned about the possibility of developing toxin-induced ptosis and mydriasis. If this occurs, after evaluation of cranial magnetic resonance imaging, doctors who applied the botulinum toxin must refer the patient to an ophthalmologist for appropriate management.

\section{Disclosure}

The article has not been presented at any meeting, and no financial support was received from any public or private source in respect to this work. The authors have no financial or proprietary interest in any product, method, or material described herein.

\section{References}

1. Münchau A, Bhatia KP. Uses of botulinum toxin injection in medicine today. BMJ. 2000;320:161-165.

2. Baggio E, Ruban JM, Boizard Y. [Etiologic causes of ptosis about a series of 484 cases. To a new classification?]. J Fr Ophtalmol. 2002;25 1015-1020. French

3. Corridan P, Nightingale S, Mashoudi N, Williams AC. Acute angleclosure glaucoma following botulinum toxin injection for blepharospasm. Br J Ophthalmol. 1990;74:309-310.

4. Zheng L, Azar D. Angle-closure glaucoma following periorbital botulinum toxin injection. Clin Experiment Ophthalmol. 2014;42: 690-693.

5. Hemmerdinger C, Srinivasan S, Marsh IB. Reversible pupillary dilation following botulinum toxin injection to the lateral rectus. Eye. 2006; 20:1478-1479.

6. Speeg-Schatz C. Persistent mydriasis after botulinum toxin injection for congenital esotropia. J AAPOS. 2008;12:307-308.

7. Levy Y, Kremer I, Shovit S, Korczyn AD. The pupillary effects of retrobulbar injection of botulinum toxin A (Oculinum) in albino rats Invest Ophthalmol Vis Sci. 1991;32:122-125.

8. Klein AW. Complications with the use of botulinum toxin. Int Ophthalmol Clin. 2005;45:163-169.

9. Omoigui S, Irene S. Treatment of ptosis as a complication of botulinum toxin injection. Pain Med. 2005;6:149-151.

10. Hirsch R, Stier M. Complications and their management in cosmetic dermology. Dermatol Clin. 2009;27:507-520.
Clinical Ophthalmology

\section{Publish your work in this journal}

Clinical Ophthalmology is an international, peer-reviewed journa covering all subspecialties within ophthalmology. Key topics include: Optometry; Visual science; Pharmacology and drug therapy in eye diseases; Basic Sciences; Primary and Secondary eye care; Patien Safety and Quality of Care Improvements. This journal is indexed on

\section{Dovepress}

PubMed Central and CAS, and is the official journal of The Society of Clinical Ophthalmology (SCO). The manuscript management system is completely online and includes a very quick and fair peer-review system, which is all easy to use. Visit http://www.dovepress.com/ testimonials.php to read real quotes from published authors. 